\title{
Public and Private Policy Change: Pension Reform in Four Countries
}

\author{
Daniel Béland and Toshimitsu Shinkawa
}

\begin{abstract}
This article offers a comparative, qualitative analysis of the changing nature of - and relationship between-public and private old age pensions in the United States, Canada, Britain, and Japan. Stressing the impact of institutional legacies on policy change, the article explains why these countries have taken contrasting paths toward the restructuring of public and private pension policies. The study finds that the four countries fall into two distinct clusters. On the one hand are Canada and the United States, which have essentially witnessed policy drift toward a greater reliance on private savings. On the other hand are Britain and Japan, which have reshaped their pension systems largely through legislative revision. The last section explains the differences between and within these two country clusters. The article concludes that institutional forces explain the distinctive policy patterns between the two country clusters but that it is necessary to bring in other factors (i.e., demographic aging, union density, and the role of ideas) to account for differences within each of these clusters.
\end{abstract}

KEY WORDS: pensions, social policy, policy change, institutions, privatization

\section{Introduction}

Since the 1980s, much has been written about the impact of fiscal austerity and free market ideas on social policy reform in advanced industrial societies. One of the most central issues debated in that comparative policy literature is the scope of policy change possible in the context of enduring institutional constraints. According to Paul Pierson (1994), the expansion of the modern welfare state during the postwar era favored the emergence of large constituencies and powerful vested interests that have prevented right-wing actors to "dismantle the welfare state." In recent years, scholars have argued that despite such institutional constraints, much policy change has occurred in advanced industrial welfare states (e.g., Hinrichs \& Kangas, 2003; Streek \& Thelen, 2005). In this debate about policy change, one of the key issues at stake is the relationship between public and private benefits (Béland \& Hacker, 2004; Hacker, 2002; Howard, 1997). Writing about the United States, Jacob Hacker has explored the incremental transformation of private benefits in a context of economic and social change. For him, incremental change in the private sector can significantly 
reduce the level of protection offered to workers despite the absence of major, direct cutbacks in public pensions and health benefits (Hacker, 2004).

In the context of this growing scholarship on policy change and the relationship between public and private benefits, detailed comparative analysis is needed to evaluate the scope and the mechanisms of policy change in countries where private social policy is a major source of economic security for workers and citizens. This article offers a systematic comparative analysis of policy changes that have affected the nature and the balance between public and private pension benefits in four advanced industrial countries since the 1970s: the United States, Canada, Britain, and Japan.

Three main factors guided the selection of these cases. The first factor (i.e., heavy reliance on private benefits) points to a major characteristic the four cases share; the two other factors (i.e., political institutions and policy ideas) stress key differences between the cases. First, as far as the policy landscape is concerned, all four countries rely extensively on private pensions. Belonging to the liberal welfare regime and offering comparatively modest public pensions, the first three countries (i.e., the United States, Canada, and Britain) are legitimate cases for such a comparative analysis as they have long featured an extended role for private pension benefits (Esping-Andersen, 1990; Myles, 1989). Moreover, these countries have modest earnings-related public pension schemes that are meant to complement private benefits. Although it possesses Bismarckian, occupationally fragmented schemes, Japan has much in common with the United States, Canada, and Britain. This is largely true because Japan, as the other three countries, features a combination of comparatively modest earnings-related public pensions and well-developed private benefits. Such common ground suggests that Japan is comparable to the three liberal countries analyzed here. Furthermore, since the mid-1980s, when it began cutting public pension benefits and overcoming institutional fragmentation, Japan has shifted considerably toward the liberal welfare regime. Overall, what Japan and the three other countries have in common is the combination of earnings-related public pension schemes with a large-scale network of private pension benefits. Second, when political institutions are considered, two of the four countries are federal systems (the United States and Canada) where power is much more fragmented than in the two other countries (Britain and Japan). ${ }^{1}$ Beyond the issue of federalism, checks and balances further increases power fragmentation in the United States. Third, at the level of policy ideas, the radical free market agenda is much less present in Canada and Japan than in Britain and the United States. Overall, these four countries share basic policy characteristics, yet major institutional and ideological differences exist between them.

This article explains why the United States, Canada, Britain, and Japan have taken contrasting paths toward restructuring of the public-private dichotomy in pension policy. Starting from the analytical distinction between two patterns of policy change (i.e., policy drift and legislative revision), the study finds that the four countries fall into two distinct clusters: Canada and the United States, which have mainly witnessed policy drift, and Britain and Japan, which have reshaped their pension systems largely through legislative revision. ${ }^{2}$ The last section explains the differences between and within these two country clusters. The article concludes that institutional forces explain the distinctive policy patterns between the two country clusters but that it is 
necessary to bring in other factors (i.e., demographic aging, union density, and the role of ideas) to account for major differences within each of these clusters.

\section{Patterns of Policy Change: Policy Drift and Legislative Revision}

During the 1990s, a common wisdom emerged in the literature about "the new politics of the welfare state." According to this common wisdom, the postwar expansion of the welfare state created powerful forces that have prevented overtly conservative politicians like Margaret Thatcher and Ronald Reagan to "dismantle the welfare state" (Pierson, 1994). Although external shocks can profoundly alter the course of a policy's development, the expansion of social programs favored the emergence of powerful economic and political constraints, such as constituencies and transition costs, making path-departing reforms unlikely (Pierson, 1996). Ultimately, these feedback effects from existing social programs lead to the enactment of path-dependent changes that seldom depart from existing institutional logics.

What is most hotly debated in the current social policy literature is the frequency of path-departing processes and the conditions under which comprehensive policy change occurs. This is largely true because the literature on path dependence and the "frozen" welfare state (Esping-Andersen, 1996) cannot account for policy transformations that emerge as the cumulative result of incremental changes (Hinrichs \& Kangas, 2003; Thelen, 2004).

In recent years, the issue of policy change has moved toward the center of the debate over social policy development in advanced industrial societies (Hacker, 2004; Pierson, 2004; Streek \& Thelen, 2005; Thelen, 2004). Perhaps the most innovative contribution to this debate is Jacob Hacker's (2004) recent article on policy drift. Borrowing from Kathleen Thelen's (2004) work on incremental change, Hacker demonstrates that a series of low-profile processes have gradually transformed the nature of the American welfare regime. Beyond the American experience, Hacker's article is relevant for the comparative literature on social policy because it gives a name to a powerful yet little-noticed mechanism of policy change that can slowly erode support for the welfare state and alter the balance between public and private benefits-generally in favor of the latter. ${ }^{3}$ Labeled policy drift, this mechanism of policy change refers to the incremental transformation of stable social policy arrangements because of shifting socioeconomic circumstances and the lack of major legislative actions to address them. According to Hacker, new socioeconomic circumstances like demographic aging and the changing nature of labor relations and family structures can make existing social programs become less and less relevant in the absence of major legislative reforms designed to adapt them to such a new environment. From this angle, legislative inaction constitutes a form of political behavior that can let existing social benefits drift away from their original purpose and meaning, thus favoring policy change that strongly affects the lives of millions of workers and citizens. In all, Hacker suggests that deep institutional change may occur in the absence of sweeping legislative action. However, as Hacker acknowledges, recognizing the potential role of policy drift should not lead scholars to abandon the study of legislative revision (i.e., the formal legislative abolition, creation, or transformation of 
social programs). Legislative revision remains a potentially major source of policy change (Hacker, 2004). The following qualitative comparative analysis will provide ground to this claim by showing how policy drift, legislative revision, or a combination of both have altered the nature of-and/or the balance between-public and private pension benefits in the United States, Canada, Britain, and Japan.

\section{Comparing Policy Paths: Policy Change in Four Countries}

This section outlines significant divergences in pension development among these four countries falling into two distinct clusters. On the one hand, the United States and Canada exhibit significant policy drift coupled with minor legislative revision. On the other hand, Britain and Japan have undertaken major legislative revisions leading to more radical policy change. The following discussion explores major differences between and within these two country clusters.

\section{Cluster One: The Prevalence of Policy Drift}

The United States. Three main parts comprise the American pension system, which is based on a complex articulation of public and private pension benefits. First, the federal Old Age, Survivors, and Disability Insurance (OASDI) is a centralized earnings-related pension scheme that covers more than 95 percent of the workforce. The largest social program in the United States, OASDI is known as Social Security. Second, the Supplemental Security Income (SSI) is an income-tested, federal assistance program offering modest benefits to needy elderly citizens. In 2003, fewer than one million retirees received SSI benefits. Finally, tax-subsidized occupational pension plans cover less than 40 percent of the working population. These plans take different forms, from traditional defined-benefit plans to individual savings accounts (Sass, 1997).

Earlier than in other countries, fiscal austerity in the United States moved onto the federal policy agenda in the mid-1970s. At the time, high rates of inflation and unemployment coupled with an overly generous indexation system enacted in 1972 necessitated the passing of significant adjustments to Social Security five years later (Berkowitz, 2003, pp. 238-39). This Social Security reform took the form of indirect benefit cuts for future retirees through the creation of a new indexation system. Furthermore, the 1977 legislation included major payroll tax hikes. A few years later, new, short-term fiscal constraints forced President Reagan to put together a bipartisan commission leading to the enactment of legislation that did not alter the structure of Social Security. In addition to relatively minor benefit cuts and payroll tax increases, this legislation made provisions for a raise in the retirement age from 65 to 67 scheduled to come into effect only between the years 2000 and 2022. Such a long phase-in period reduced political risks stemming from this controversial measure (Light, 1995). Overall, the 1983 reform solved the short-term fiscal imbalance in Social Security. Since the mid-1980s, this program has even moved toward partial advanced funding, thus accumulating reserves sufficient to guarantee Social Security's actuarial soundness for several decades to come (Derthick, 2001; Weaver, 2005). ${ }^{4}$ 
Immediately after the enactment of the 1983 amendments, those seeking to transform Social Security adopted what right-wing experts Stuart Butler and Peter Germanis (1983) labeled a "Leninist strategy." According to this strategy, the only way to reshape Social Security was to gradually weaken existing support for this program, notably through the expansion of tax-sponsored, private savings schemes grounded in a defined-contribution logic at odds with Social Security's definedbenefit model (Butler \& Germanis, 1983). Two trends have favored the expansion of private savings schemes. First, since the mid-1980s, Congress has enacted new tax incentives supporting the multiplication of private savings accounts. Second, since the late 1970s, many employers have moved away from traditional definedbenefit plans in order to shift economic risks from the firm to workers. In such a context, the United States has witnessed the rapid multiplication of 401(k)s and other tax-sponsored savings schemes (Hacker, 2002). ${ }^{5}$ This incremental expansion of private savings further diffuses the "financial culture" (i.e., the taste for and the knowledge about stock market investment) among the middle class and, in the long run, could reduce its support for Social Security (Teles, 1998). This second development constitutes a form of policy drift largely because firm-level governance, not direct legislative revision, is the main source of change. Furthermore, the absence of Social Security reform since 1983 has created a situation under which the program has not adapted to changing social and economic circumstances (Béland, 2007).

Another aspect of the "Leninist strategy" is the push for Social Security privatization (i.e., the transformation of the program into a system of personal savings accounts). Since the mid-1990s, many conservative experts and politicians have promoted this alternative on the federal policy agenda (Quadagno, 1999). As early as the 2000 presidential campaign, George W. Bush himself endorsed Social Security privatization. The peak of his campaign in favor of that alternative occurred in the months following his reelection in 2004; however, his campaign went nowhere (Dionne, 2005).

Following Jacob Hacker, one can argue that the absence of comprehensive legislative revision (i.e., Social Security privatization) in the United States should not be understood as proof that "nothing has happened" in that country's pension system. As mentioned earlier, the multiplication of savings schemes in the private sector and the related decline of defined-benefit plans is the symptom of a major form of policy drift resulting in part from the changing behavior of employers intent on abolishing job security and shifting financial risks onto workers. In the absence of major legislative actions capable of reducing their negative impact, these trends seriously weaken employment-based protection (Hacker, 2004). This means that despite the absence of comprehensive restructuring in the existing public pension system, millions of American workers are less protected against old age insecurity than before. From the perspective of the public-private dichotomy, much has changed in the American pension system since the 1980s despite the failure of the campaign to privatize Social Security. Considering the unwillingness of federal policymakers to expand Social Security and SSI in order to compensate for declining levels of private protection, substantial policy drift is taking place in the United States. 
Canada. Like the three other countries under analysis here, Canada has a pension system grounded in the articulation between public and tax-sponsored private benefits. A relative latecomer, Canada only developed a comprehensive public pension system in the 1960s. This system is divided into three tiers: (i) Old Age Security (OAS), a universal flat-rate pension supplemented by a Guaranteed Income Supplement (GIS) providing assuring income to poorer elderly citizens, both financed from general revenue; (ii) the Canada Pension Plan (CPP) and the Quebec Pension Plan (QPP), earnings-related pension programs financed from payroll contributions (benefits from either scheme are based on pension credits accumulated under both as if only one scheme existed); and (iii) private yet tax-subsidized defined-benefit Registered Pension Plans (RPPs) and personal retirement savings accounts known as Registered Retirement Savings Plans (RRSPs) (Béland \& Myles, 2005).

In Canada, retrenchment attempts were launched in the mid-1980s and finally materialized in 1989, when the Mulroney government implemented a "clawback" of OAS benefits from wealthy elderly citizens. At first, such low-profile reform affected only a small number of elderly citizens, and few citizens and journalists understood its longer-term implications. This explains why the measure, which garnered so little media and political attention, was successfully introduced in the first place (Battle, 1990). Given low levels of inflation and income growth in the 1990s, the measure affected less than 5 percent of all elderly citizens by the end of that decade. In 2000, the Liberal government of Jean Chrétien restored full indexation, which meant that future savings from the "clawback" would remain modest. Moreover, facing much popular opposition, the Chrétien government withdrew the 1996 legislative proposal that would have cut OAS/GIS benefits through the introduction of the so-called Seniors Benefit. From this angle, the attempt to significantly cut OAS benefits failed (Béland \& Myles, 2005).

At the era of pension restructuring, the C/QPP constituted a larger target, despite the fact that payroll contribution remained modest in the mid-1990s, and that this program offered a small replacement rate of 25 percent. As in Britain and the United States, some economic and political actors promoted the idea of using pension contributions to feed the financial industry and stimulate investment, increase national savings rates, and promote the virtues of economic ownership and self-reliance (e.g., Reform Party, 1998). Following their American counterparts, Canadian privatizers hoped that the expansion of private, tax-assisted savings schemes would provide both a model and a further rationale for pension privatization (Townson, 2001). Yet, in contrast with the American situation, the issue of pension privatization was never maintained on the federal policy agenda.

Rejecting privatization at an early stage of the consultation process between Ottawa and the provinces, the Chrétien government presented the draft of the new CPP legislation in February 1997. The first major aspect of that plan was to increase the total rate of employer and employee CPP contributions from 5.6 to 9.9 percent by 2003. As a result of this reform, the reserve fund would grow from 2 to 5 years of CPP benefits. This surplus would be invested in a diversified financial portfolio "to earn higher returns and help pay the benefits as Canada's population ages" (Martin, 1997). In order to invest the reserve fund, the federal government would set up a 
CPP Investment Board, an independent organization managed by investment professionals from the private financial sector. In addition to these proposals, the CPP legislation enacted in January 1998 included relatively minor modifications, which were to improve the long-term financial situation of that program. For example, "retirement pensions will be calculated on the 5-year average of the Year's Maximum Pensionable Earnings at the time, instead of the 3-year average" (Martin, 1997). In order to maintain a high level of coordination between the QPP and the CPP, Quebec's legislature enacted the same bill at the provincial level. Instead of departing from the institutional path of C/QPP, the 1997 reform reaffirmed its contributory approach of the C/QPP, while avoiding an increase in retirement age similar to the one enacted 14 years earlier in the United States.

As in the United States, however, the absence of path-breaking legislative revision (i.e., privatization) does not mean that nothing significant has happened in the Canadian pension system since the 1980s. Over the last two decades, personal retirement savings accounts (RRSPs) have considerably expanded (Townson, 2001). In only eight years, between 1993 and 2001, "the number of people contributing to RRSPs increased by more than 25 percent" (Statistics Canada, 2004). In Canada, the comparatively modest level of public pension contributions (C/QPP) leave enough room for middle- and upper-class individuals to save, and, in an atmosphere of demographic pessimism (Prince, 2000), saving for retirement is increasingly seen as the only reasonable way to prepare for retirement. Furthermore, like Britain, Japan, and the United States, Canada has witnessed a decline in coverage of workplace pension plans (RPPs). ${ }^{6}$ When both defined-benefit and defined-contribution pensions are factored in, Canada enjoys a similar rate of private pension coverage as the United States (approximately 40 percent) and the two countries exhibit comparable patterns of policy change as they have experienced no comprehensive legislative revision, the emergence of new socioeconomic trends such as the decline of job security and the growing popularity of tax-subsidized saving schemes like the RRSPs. This means that despite the absence of systematic legislative revision in the field of public pensions, both Canada and the United States have witnessed policy drift toward a greater reliance on private savings.

Yet, one should recognize that although they belong to the same country cluster, Canada and the United States are far from being identical cases. First, the decline of defined-benefit pension schemes has been less dramatic in Canada than in the United States. In Canada, more than 80 percent of private sector workers covered by private schemes are entitled to defined-benefit pensions. This percentage is much lower in the United States (Luchak, Fang, \& Gunderson, 2004, p. 469). Additionally, pension (State Earnings Related Pension Scheme or SERPS) privatization has never moved to the center of the national policy agenda in Canada, thus remaining a marginal policy alternative.

\section{Cluster Two: The Prevalence of Legislative Revision}

Britain. Compared with more generous public pension schemes in continental Europe, the postwar British public pension system offered relatively low benefits, 
leaving room for occupational pensions (Myles, 1989). By the late 1970s, the British public pension system had three tiers: a modest flat rate universal pension, meanstested benefits for the poor, and, an earnings-related program enacted only four years (SERPS) before Thatcher came to power in 1979. SERPS would not start to pay full benefits until 1998. In addition to that public system, almost 50 percent of the British workforce was enrolled in firm-based occupational pension plans. When SERPS came into effect in 1978, officially approved occupational plans had the opportunity to opt out of the program and the large majority of the established occupational plans were actually approved (Fawcett, 2002, p. 10).

The adoption of the 1980 Social Security Act represented a first step in the Conservative promotion of private savings and occupational pensions. In order to facilitate a gradual decline in the real value of the flat pension, this reform initiated a move from earnings indexing to inflation indexing. This change reduced the level of public pension spending and, as conservatives hoped, increased the demand for private savings and occupational pensions. Yet, at that time, this seemingly modest and technical reform did not become highly controversial because few understood the negative impact of the new indexation model on public pension benefits. The public was misled by Thatcher's words that the British state did not eliminate indexation (Pierson \& Weaver, 1992, pp. 130-31).

Half a decade later, the second Thatcher government pushed for a much more radical reform that could durably transform the balance between public and private benefits in Britain, that is, the abolition of SERPS, a program Conservatives perceived as an obstacle to the expansion of private savings and occupational pensions. Unfortunately for them, Thatcher's 1985 attempt to eliminate SERPS failed in the face of strong criticisms emanating from both labor and business circles. Even the British treasury opposed the plan (Bonoli, 2000, p. 72). Yielding to such protests, the second Thatcher government modified its proposal in December 1985 (HM Department of Health \& Social Security, 1985). Instead of terminating SERPS, the Thatcher government proposed to cut benefits and to make opting out more attractive for current participants, which, to the great satisfaction of Conservatives, would erode support for SERPS and stimulate the growth of personal savings and occupational pensions. Although the plan caused a stir among trade unions and antipoverty organizations (Bonoli, 2000, pp. 76-77), the Parliament enacted it as part of the 1986 Social Security Act (Glennerster, 2000, p. 170). This legislation reduced the SERPS replacement rate from 25 percent of the best 20 years of earnings to 20 percent of lifelong earnings (Fawcett, 2002, p. 13). Moreover, beginning in 1988, current SERPS participants could opt out of it for opening a private savings account ("personal pension"). As a consequence of these new provisions, the number of SERPS participants dropped from 10.9 to 6.5 million between 1987 and 1994. By 1994, the number of former SERPS members who had opted for a "personal pension" reached 5.7 million (Bonoli, 2000, p. 80). During the 1990s, however, the "misselling scandal" seriously undermined the popularity of the personal pensions created in 1986. This scandal occurred when it was revealed that the financial industry gave bad advice to a large number of workers who opted out of SERPS while it would have been more advan- 
tageous not to do so. The public outcry surrounding the "misselling scandal" forced British policymakers to enact new regulations, which ended up costing billions of pounds to the insurance industry (Blake, 2000; Jacobs \& Teles, 2006; Teles, 1998).

The successive Blair governments, 1997-2007, enacted significant reforms like the creation of a State Second Pension for lower-income workers, which replaced SERPS. Yet, these "New Labour" governments promoted the ongoing development of personal savings. For example, the 1999 Welfare Reform and Pensions Bill implemented a portable Stakeholder Pension: a new, tightly regulated personal savings scheme targeting lower-income workers and grafted onto the private second tier of the British pension system. Considering that British public pensions are modest in scope (i.e., low replacement rate) and that the private pension system is loosely regulated, the current British debate on pension reform is concerned with the adequacy of the existing public provisions and their ability to effectively fight poverty and economic insecurity among the present and the future elderly population (Taylor-Gooby, 2005). In a context of strong public disenchantment with the existing pension system and enduring concerns with relatively high poverty rates among the elderly, 72006 White Paper inspired by the work of the Pensions Commission (Price, 2007) led to the enactment of the controversial Pensions Act 2007, which increases retirement age for the state pension and promoted gender equality while leaving much room for private pensions and savings. ${ }^{8}$

Overall, since the early 1980s, major legislative revision in Britain has reinforced the role of the private sector and personal savings at the expense of public provisions.

Japan. Japan's modern public pension system emerged as a complex and occupationally fragmented, Bismarckian social insurance model. Created during the World War II, the first public pension scheme for private sector workers was later rearranged into the Employees' Pension Plan (EPP) by extending coverage to those excluded from the original plan, such as white-collar workers, female workers, and employees of establishments holding between five and nine employees. ${ }^{9}$ As public pension schemes had been paralyzed during the period of turmoil following the end of the World War II, employers began providing retirement payments in response to workers' demands, which developed into tax-qualified pension plans (TQPs) in 1962. Moreover, four years later, the government introduced legislation to allow employers to opt out of the earnings-related part of the EPP and create their own plans called the Employees' Pension Funds (EPFs). Corporate pension schemes existed as a purely private system (TQPs), whereas the EPFs substituted for the second tier of the EPP. As such, EPFs were under stricter controls and regulations than TQPs and they enjoyed more generous tax treatment. ${ }^{10}$ Made compulsory in 1961, the National Pension Plan (NPP) covered those excluded from employers' schemes: farmers, the self-employed, and employees of small businesses. The NPP was based on the social insurance model, but while EPP distributed both flat-rate and earnings-related benefits, NPP only offered flat-rate benefits.

Institutionally divided pension schemes without financial transfers between them can only survive under specific conditions: at such a time when population aging is limited ${ }^{11}$ and the economy is expanding so rapidly that it can redistribute 
wealth through subsidies and generous loans to the declining economic sectors. In Japan, these favorable conditions had faded away by the early 1980s and the system's institutional vulnerability became obvious in sectors like agriculture and the national railway. This is why the National Railway Mutual-Aid Plan and the NPP suffered deficits on an annual basis as early as the first years of the 1980s. As a response to this major institutional challenge, the 1980s witnessed the introduction of fiscal adjustment across different public pension schemes. Moreover, the National Railway Mutual-Aid Plan was merged with the other mutual-aid plans of public corporations. Finally, in order to reduce NPP deficits through fiscal transfers, the government created the Basic Pension by integrating the NPP with the EPP flat-rate tiers and the mutual-aid plans (Shinkawa, 2005).

During the 1990s, a series of comprehensive reforms were enacted in Japan. The 1994 and 1999 reforms favored a gradual increase in the retirement age from 60 to 65. The 2004 reform initiated a shift from defined-benefit to defined-contribution by setting the upper-limit of future payroll tax rates. Along with public pension reform, the entire structure of corporate pensions was overhauled in 2001. The TQP (private pensions) will be terminated by the end of fiscal year 2011. Instead, a "contract type" of plan will be introduced. The contract type is similar to the TQP, yet it stipulates a clear obligation for the employer to maintain specific asset levels while facilitating asset transfers between distinct pension plans.

Even more significant is the introduction of the defined-contribution scheme, which is widely known as the "Japanese version of 401(k)." The defined-contribution plan is expected to transfer the risk and responsibility of pension protection from employers to their employees, and it provides full portability of pension assets. It is too soon to identify which type of pension plan will become dominant in the future, but the defined-contribution approach is gaining ground in a society where the "job for life" model and the related economic security are declining. As of April 2003, firms having defined-contribution plans reached over 400. As in the three other countries discussed earlier, smaller firms are more likely to adopt such plans that reduce their financial and administrative burden (Nenkin Joho Henshubu, 2003, pp. 94-100).

To ease anxieties about the sustainability of the public pension system, the 2004 reform stipulated that the contribution rate of employees would be raised gradually from the current 13.58 percent of annual income to 18.3 percent by 2017 and kept at that level thereafter. Benefit levels would vary according to changes in demographic and economic factors, including life expectancy, fertility rates, interest rates, and prices, and not on the basis of political decisions. In short, pensions will shift from defined-benefit to defined-contribution. The government insists that this legislative revision has reduced inequality between age cohorts. The current level of benefits would decrease by approximately 10 percent by 2017 but be maintained at that level thereafter. However, the reform failed to introduce a device that would guarantee a replacement rate of above 50 percent-except for the obscure clause stipulating that the government would reconsider the plan when the replacement rate would decline below 50 percent. Just before the Diet passed the bill, the Welfare Ministry acknowledged that if the current predictions about economic growth, prices, and fertility 
rates were accurate, benefits delivered under the new scheme would start with 50 percent of the average salary, before declining substantially afterward (Nihon Keizai Shinbun, May 13, 2004).

Overall, major legislative actions helped Japan move from an essentially Bismarckian logic to a liberal pension regime leading to a potentially major decline in workers' economic security. Consequently, as in Britain, comprehensive policy change occurred largely through legislative revision. Although the scope of policy change proved slightly more comprehensive in Japan than in Britain, both countries undoubtedly belong to our second country cluster.

\section{Discussion}

The presentation provided earlier of recent pension trends in the United States, Canada, Britain, and Japan points to the contrast between two country clusters. On the one hand, Canada and the United States (Cluster One) witnessed no profound legislative revision in the public pension sector, but incremental change related to shifting socioeconomic conditions in the absence of bold legislative actions did affect private benefits, leading to policy drift. In both countries, the absence of comprehensive legislative revision has not prevented an incremental restructuring of tax-sponsored private benefits in the sense of a greater reliance on definedcontribution schemes. On the other hand, Britain and Japan (Cluster Two) mainly took the road of legislative revision by enacting major changes to the public pension system. Both countries witnessed major legislative revisions that transformed the balance between public and private benefits as well as the nature of private provisions.

The contrast between these two country clusters should not hide internal differences within each cluster. As mentioned earlier, there are two major differences between Canada and the United States. First, Canada exhibits a slower decline in private defined-benefit schemes. Second, while Social Security privatization has emerged as a major policy issue in the United States, this issue has seldom been brought up on the Canadian policy agenda. Within Cluster Two, the main difference between the two countries is the greater level of legislative revision taking place in Japan than in Britain.

The task ahead is to explain these cross-national differences through two distinct pairs of comparisons. First, in order to explain the prevalence of one type of policy change over another (i.e., policy drift versus legislative revision), we will compare Cluster One (Canada and the United States) to Cluster Two (Britain and Japan). Second, we will examine differences between the two countries within each cluster (i.e., Canada versus the United States; Britain versus Japan). This two-step comparison requires us to draw upon several theoretical approaches: historical institutionalism explains major differences between the two country clusters; factors related to other approaches (i.e., demographic change, labor mobilization, and the politics of ideas) explain differences between countries belonging to the same cluster. 


\section{Four Theoretical Approaches}

Historical Institutionalism. Over the last two decades, historical institutionalism has emerged as the most prominent approach to social policy change (e.g., Bonoli, 2000; Hacker, 2002; Pierson, 1994; Pierson \& Weaver, 1992; Skocpol, 1992). The historical institutionalist literature is based on the assumption that established policies and formal political institutions constrain trajectories of policy development. On the one hand, the constituencies and vested interests that previously enacted the policies created strongly impact policymaking processes. For example, the emergence of large armies of beneficiaries that oppose policy cutbacks and restructurings can generate electoral risks and reduce the willingness of policymakers to pursue legislative revision (Campbell, 2003). Recent institutionalist scholarship suggests that private policies may generate powerful vested interests that impact future policy decisions in both the public and the private sectors (Hacker, 2002). Regarding pension reform, this means that the nature of the existing public and private schemes affects the prospect for policy change. On the other hand, historical institutionalism states that formal political institutions impact the manner in which interests mobilize within the policy process. Furthermore, formal institutional settings-like the parliamentary system-create particular incentives and obstacles for elected officials seeking to establish new programs or to reform existing ones. In the field of pension reform, this suggests that greater power concentration can facilitate legislative revision. Yet, power concentration is a double-edged sword, as it can exacerbate the electoral risks those in power face when pursuing potentially unpopular reforms (Pierson \& Weaver, 1992; Weaver, 1986).

Predominant as it is, historical institutionalism is not the only theoretical perspective on policy change. In the literature on social policy, one can identify three major theoretical approaches that the founders of historical institutionalism criticized in order to establish its scholarly legitimacy (Skocpol, 1992). ${ }^{12}$ These three approaches respectively focus on the following factors: economic and demographic change, labor power, and the role of ideas and discourse.

The fact that founders of historical institutionalism criticized these approaches has not prevented other scholars to rightly stress the fact that such approaches can complement historical institutionalism in order to explain complex policy change (Campbell, 2004; Myles \& Quadagno, 2002). Moreover, while these three approaches were formulated to explain the emergence and the expansion of the welfare state, they emphasize factors that can help explore the politics of retrenchment and restructuring (Béland, 2007; Myles \& Quadagno, 2002). The following analysis provides ground to these two claims.

Industrialism. The first perceived alternative to historical institutionalism is the demographic and economic approach known as industrialism. For this approach, economic and demographic change is the root cause of modern welfare state development. In The Welfare State and Equality, for example, Wilensky argues that population aging related to industrialization is the most essential factor at the origin of modern social policy development (Wilensky, 1975). Although one cannot deny the 
Table 1. Forecasts of the Old Age Dependency Ratio

\begin{tabular}{lcc}
\hline Country & 2010 & 2030 \\
\hline Canada & 0.20 & 0.35 \\
Japan & 0.35 & 0.47 \\
United Kingdom & 0.27 & 0.42 \\
United States & 0.21 & 0.35 \\
\hline
\end{tabular}

Source: England (2001).

overall tendency that industrialization is one of the basic conditions of modern social policy development, there is strong evidence that industrialism is unable to explain significant variations across and within economically advanced nations in terms of policy design and social spending (Myles \& Quadagno, 2002). Moreover, because industrialism appeared as an approach aimed at explaining the emergence of the modern welfare state, it is not satisfactory for explaining variations in social policy development, not to mention retrenchment and restructuring (Pierson, 1994).

Although industrialism is a flawed tool to explore contemporary policy change, this approach draws our attention to the central role of demographic aging, which constitutes the necessary background of existing pension studies (e.g., Myles, 1989). From this perspective, one could argue that differences in the scope and pace of demographic aging can impact policy change in the field of old age pensions. To a certain extent, this type of explanation would not contradict historical institutionalist assumptions, as indicated by Paul Pierson's arguments stressing the role of external economic and demographic pressures in accounting for path-departing policy change (Pierson, 2000). Our comparative analysis provides ground to the idea that massive demographic change is likely to encourage political actors to embrace path-departing legislative revision. The comparison between Japan and Britain provides ground to this claim. As the country with the most significant scope of demographic change (Table 1), Japan enacted more comprehensive legislative changes than Britain. Yet, demographic change only takes its meaning in the context of existing policy legacies. In Japan, the precarious fiscal situation created by the fragmentation of postwar public pension legacies explains why demographic change had such a strong policy impact. Second, demographic change in itself cannot explain variations between the two country clusters. For example, although both Britain and Japan have experienced major legislative revisions, Britain experienced much weaker demographic pressures than Japan when it witnessed major legislative revision in the mid-1980s. Overall, Thatcher's pension restructuring had less to do with demographic aging per se than with the neoliberal push for a greater role of financial markets and personal savings in the British pension system. This ideological push provided the main rationale for the 1986 legislative revision (Teles, 1998).

This comment about Britain points to the reason why demographic variations do not explain major differences in policy patterns between our two cases. Although Table 1 shows that the long-term demographic challenge is greater in Britain and Japan (Cluster Two) than in Canada and the United States (Cluster One), this factor cannot account for the logic behind the enactment of the 1986 Social Security Act. 
Furthermore, as previously suggested, the demographic challenge was more serious in Japan than in the three other countries largely because of the institutional vulnerability of its pension system. This discussion suggests that simply looking at the demographic data is potentially misleading. In countries like Britain and the United States, the predominance of the market ideology is more critical to the politics of public and private pensions than demographic change per se. This is particularly striking in the case of Social Security privatization and the multiplication of taxsponsored saving schemes (Béland, 2007). This is why, in itself, demographic factor is unable to explain the main differences in policy patterns between our two country clusters.

Power Resource. Formulated in the late 1970s and early 1980s, the power resource theory constitutes the most debated perceived alternative to historical institutionalism. Yet, both theories can complement one another, as some studies suggest (e.g., Huber \& Stephens, 2001). The power resource approach assumes that the welfare state is an effect of labor mobilization, thus implying that the balance between public and private pension provisions largely depends on labor's strength (e.g., EspingAndersen \& Korpi, 1984; Korpi, 1978; Myles, 1989). Although this approach emerged to explore the politics of welfare state expansion, a number of scholars have recently argued that labor power, in this case "incumbency of political parties based on the organizational power of the working and lower-middle classes" remains a key political variable in the era of retrenchment and restructuring (Huber \& Stephens, 2001, p. 41; see also Korpi \& Palme, 2003). From this perspective, it is predicted that the most resilient to welfare retrenchment are countries where organized labor and its affiliated parties remain strong.

A power resource approach to welfare retrenchment and restructuring appears ineffective in explaining major variations in policy patterns between our two country clusters. This is true because, since the 1980s at least, the four countries under study have featured comparatively weak labor parties and movements (e.g., Card, Lemieux, \& Riddell, 2003). Furthermore, the country that has the weakest labor movement in terms of union density and political influence- the United States-has not witnessed any path-departing legislative revision of its public pension system. Yet, the power resource approach provides insight to our comparative analysis because labor unions often play a central role in the development of private pension benefits (e.g., Klein, 2003; Sass, 1997). As the comparison in the succeeding discussions between Canada and the United States (Cluster One) suggests, cross-national variations in unionization rates (that reflect the strength of organized labor in the private sector) can influence the transformation taking place at the firm level, which, in turn, can facilitate policy drift. This is why it is important to explore the role of labor unions when we attempt to account for differences within Cluster One, where policy drift is featured prominently.

The Study of Ideas. This type pf approach to historical institutionalism is grounded in the assumption that changing political discourses (Schmidt, 2002) and policy paradigms (Hall, 1993) help create the "need to reform" the welfare state (Cox, 2001), 
frequently in favor of the free market project (i.e., retrenchment and privatization). Ideas become important when we analyze the contrast between Britain and the United States, on the one hand, and Canada and Japan, on the other hand. The first pair mentioned witnessed the emergence of coherent and radical free market projects known as Thatcherism and Reaganism, whereas the latter experienced only moderate free market agendas, which rarely feature strong antigovernment rhetoric, as seen in Britain and the United States (Nash, 1996). Although Canada and Japan share the weakness of radical free market ideas, they belong to different clusters. On the one hand, Japan has had the greatest degree and extent of policy change through legislative revision. This fact places Japan in Cluster Two. On the other hand, among our four cases, Canada is the country that has witnessed the least legislative revision, which explains why it falls so clearly into Cluster One. The contrast between Britain and the United States is also striking. Although they both witnessed the crystallization of a coherent and radical free market discourse, Britain implemented more significant legislative reforms than the United States in the 1980s (Pierson, 1994). In Britain, these reforms extended to policy areas like unemployment and work accident benefits (Korpi \& Palme, 2003). Although market-oriented ideas guided these reforms, only institutional factors can explain why Margaret Thatcher went further in implementing these ideas than Ronald Reagan, who embraced the same ideological creed (Pierson, 1994).

The study of ideas is not the appropriate approach to explain the gap in policy patterns between our two country clusters, but paying attention to ideas is useful in order to account for one major difference within Cluster One. As the comparison between Canada and the United States shows, turning to ideas can complement institutional analysis. The fact that radical free market ideas are less prevalent in Canada than in the United States substantially explains why pension privatization is a far more marginal policy alternative in Canada. As seen in the next section, the federal structure of the CPP also played a significant role in marginalizing the idea of pension privatization in Canada. Here, the study of policy ideas works hand in hand with institutional analysis, thereby bringing about different policy effects within Cluster One.

The following analysis has two distinct stages. Exploring differences between the two country clusters, the first stage shows why historical institutionalism is so effective at explaining them. This stage of the analysis stresses the impact of policy legacies and formal political institutions on policy change. In order to explain major differences within each cluster, the second stage of the analysis brings in factors associated with the three other approaches (i.e., demographic change, labor power, and the role of ideas).

\section{Explaining Differences between the Two Country Clusters: An Institutionalist Perspective}

As previously suggested, institutional variations explain the gap in policy patterns between Britain and Japan (Cluster Two) and the United States and Canada (Cluster One). In Britain, the nature of existing policy legacies principally explains 
why major changes in the public pension system were possible in the 1980s. As SERPS had only been enacted in 1975, the so-called "double payment" problem (i.e., workers must finance the pensions of current beneficiaries while saving for their own retirement) was far less serious than in other countries that facilitated partial privatization. Moreover, SERPS had no beneficiaries in the mid-1980s, which means that this social program had yet to create strong constituencies and vested interests in British society. Finally, the fact that the members of approved private pension plans had the opportunity to opt out of SERPS from the outset, weakened popular support for the program (Pierson, 1994).

Policy legacies are also crucial in explaining the central role of legislative revision in Japan. As stated earlier, this country began the process of pension retrenchment and structuring back in the mid-1980s, a decade before population aging became a serious fiscal threat to the public pension system. This early wave of policy restructuring occurred largely because particular schemes suffered fiscal tightness because of the absence of institutional mechanisms to disperse growing financial burdens through transfers across occupationally fragmented pension schemes. Ironically, therefore, the fragmentation of existing pension legacies provided a strong rationale for path-departing reforms as Japanese policymakers easily legitimized pension restructuring, thus stimulating the development of private savings and defined contribution schemes in the name of "rationalization." Consequently, growing concerns about population aging that emerged in the 1990s only accelerated path-departing reforms instituted as a reaction against unsustainable policy legacies (Shinkawa, 2005).

As compared to Britain and Japan, Canada and the United States feature major institutional obstacles to comprehensive legislative revision. In the United States, the interaction of divided government and strong vested interests related to the postwar expansion of Social Security make comprehensive reform unlikely. First, the fragmentation of power at the federal level and the related multiplication of legislative "veto points" make any controversial reform difficult to enact (e.g., Pierson, 1994). Second, Social Security is a mature and unified pension program that has created strong vested interests and electoral risks for politicians who dare attack it. The imposing membership of the American Association for Retired Persons is the symbol of the powerful institutionalized opposition to Social Security restructuring. In addition to the role of this organization, the political weight of elderly voters partly related to the development of Social Security itself constitutes a major source of electoral risks for federal politicians (Campbell, 2003).

In Canada, institutional obstacles to reform include similar opposition to restructuring from beneficiaries and the nature of the policymaking structure of the C/QPP. As the federal and provincial governments share constitutional responsibility for the $\mathrm{C} / \mathrm{QPP}$, Ottawa must reach an agreement with at least two-thirds of the provinces with two-thirds of the population prior to enacting a reform (Banting, 1987; Battle, 1997, p. 538). This means that provinces have a "veto point" in C/QPP reform. Quebec, which manages the autonomous QPP, enjoys a strategically advantageous position, as any significant CPP reform can hardly take place without the enactment of an identical reform in that province. In the mid-1990s, privatization-as much as 
direct cuts in benefits-was quite an unpopular policy alternative in Quebec. As the request not to alienate Quebec voters became stronger than ever after the 1995 referendum, which the separatists were so close to winning, privatization became implicitly linked to the issue of "national unity." Consequently, the existence of provincial "veto points" stemming from the consultative nature of C/QPP reform helps explain why radical proposals requiring comprehensive legislative revision never entered the Canadian policy agenda in the 1990s (Béland \& Myles, 2005).

\section{Explaining Differences within Each Cluster: Bringing Three Other Factors in}

The historical institutionalist perspective helps explain the contrast between the two country clusters. To account for differences within each cluster, however, we need to introduce the three factors traditionally associated with other approaches discussed previously.

Demographic Aging. Regarding Britain and Japan (Cluster Two), the broader scope of legislative revision in the latter country is related to the largely uncontested inability of the existing, highly fragmented public pension system to cope with rapid demographic change. As aforementioned, Japan needed to accomplish a comprehensive reform to overcome financial vulnerability embedded in institutionally fragmented schemes. The country's expected massive demographic change reconfirmed the necessity of an overhaul of fragmented pension schemes, while empowering bureaucrats and political actors sought to pass pension responsibilities from the state to employers and workers. The data presented in Table 1 point to the particularly severe impact of demographic aging in Japan. In view of these data and of the current Japanese policy debate, it is hard to deny that the greater scope of demographic change has become a major motivation for policy change in Japan. In the other cluster composed of Canada and the United States, the impact of population aging is less serious and demographic variations between these countries cannot explain the aforementioned policy differences between them (i.e., lack of major privatization debate in Canada and stronger pace of policy drift in the United States).

Labor Power. As previously mentioned, two differences are remarkable within Cluster One: the slower pace of incremental change in the Canadian private pension system and the absence of the privatization issue on the policy agenda in Canada. Regarding the slower pace of incremental change, historical institutionalist explanations are ineffective because the slower decline in defined-benefit pensions that makes policy drift less dramatic in Canada than in the United States is related to the higher unionization rate stemming only partly from the higher level of public sector employment in Canada (Luchak et al., 2004). Between 1975 and 1981, the total membership of trade unions in the United States remained relatively stable, but the density ratio fell from 28.9 to 22.6 percent. By 1991, it had dropped to only 16.1 percent. This fall more or less reflected a decline in labor's influence at both the political and the enterprise levels (Galenson, 1996, pp. 2-3). In contrast, no sharp 
decline in union membership has been witnessed in Canada, where the unionization rate has remained relatively stable at about 30 percent of the workforce. These stronger unions have often opposed the shift from defined-benefit to definedcontribution schemes (Townson, 2001). The much higher unionization rate in Canada and the tendency of many Canadian unions to oppose the demise of defined-benefit schemes largely explains the slower shift from defined-benefit to definedcontribution pensions in that country than in the United States. As the unionization rate is higher and more stable in Canada, firms seeking to transfer pension risks onto workers' shoulders face stronger potential resistance than in the United States. In the other cluster composed of Britain and Japan, the labor factor is ineffective at explaining key differences between these two countries. This is true partly because, like the United States, both countries experienced sharp falls in union density. ${ }^{13}$ Direct political attacks against the labor movement through privatization of public corporations in Japan and legislative reforms in Britain worsened the situations in both countries.

The Role of Ideas. As for the absence of major public discussions about pension privatization in Canada, the previously stated analysis suggests that it is related to the institutional structure of the C/QPP. This federal structure makes controversial reforms like pension privatization unlikely in the context of provincial "veto points." Along with that, the absence of heated debates over privatization has another cause pointing to the role of ideas in policymaking: the marginal status of a radical free market and an antigovernment discourse in Canada (e.g., Abelson, 2002). As opposed to the United States, in recent decades, Canada has not witnessed the emergence of this type of discourse as a mainstream component of the policy landscape. Although free trade and fiscal responsibility have dominated the Canadian policy since the 1980s, unilateral attacks against the welfare state are all but marginal in mainstream political discourse and policy debates. Overall, this factor, combined with the federal structure of the C/QPP discussed earlier, ${ }^{14}$ largely explains why pension privatization has remained such a marginal policy issue in Canada (Béland \& Myles, 2005).

Interestingly, if the role of ideas helps explain a significant difference between Canada and the United States, this factor is unable to shed new light on the most central difference between the countries comprising Cluster Two. Although the radical market agenda has proved far more influential in Britain than in Japan, it is the latter country that witnessed the most comprehensive forms of legislative revision leading to retrenchment and restructuring. As stated ealier, the greater scope of demographic change and the related unsustainability of existing policy legacies in Japan largely explain why this country has witnessed bolder legislative revision than Britain.

\section{Conclusion}

This article backs the claim that "the new politics of the welfare state" is concerned as much with policy drift and the changing relationship between public and 
private benefits as with formal legislative revision directly reshaping public social programs. The four countries under study have all attempted to control public pension spending while increasing the reliance of workers and citizens on personal savings. Yet, looking closely at these apparently similar cases, one perceives the diversity of institutional paths to pension retrenchment and restructuring. Drawing on the analytical distinction between policy drift and legislative revision, the analysis emphasizes the existence of two clusters among our four cases: Canada and the United States, on the one hand, and Britain and Japan, on the other hand. Whereas policy drift is the dominant source of policy change in Canada and the United States (Cluster One), legislative revision plays a much greater role in reshaping existing pension systems in Britain and Japan (Cluster Two).

The comparison between these two clusters emphasizes the potentially central role of incremental change and policy drift in policy development, while suggesting that legislative revision remains a major possible source of policy change. Pension restructuring is about the changing balance between policy drift and legislative revision. This comparative analysis also suggests that the factors historical institutionalism stresses (i.e., political institutions and policy legacies) explain the major difference in policy patterns between our two country clusters (i.e., emphasis on legislative revision or on policy drift). As for explaining major differences within each of these clusters, this analysis brings in three factors traditionally distinct from historical institutionalism: demographic aging, labor mobilization, and the politics of ideas. First, the fact that Japan faces such a massive demographic transformation helps explain why this country undertook more comprehensive forms of legislative revision than Britain. Second, variations in union membership rates largely account for a key policy difference between Canada and the United States (i.e., the lower level of policy drift in the former country). Third, taking ideas and discourse into account shed light on another major difference between Canada and the United States: the lack of push for pension privatization in the former country.

Overall, our analysis suggests that supplementing historical institutionalist explanations with factors associated with other approaches is a fruitful way to offer a systematic analysis of all the major differences between our four cases. This is especially true because stressing the role of demographic aging, labor mobilization, and the politics of ideas does not challenge the basic assumptions of historical institutionalism (Béland, 2007). Instead of viewing the four theoretical approaches featured in the discussion section as incompatible, social scientists may combine them in order to understand better complex forms of policy change such as those involving the changing boundaries between public and private benefits (Campbell, 2004; Myles \& Quadagno, 2002). In future research, scholars could attempt to extend such a constructive dialogue between existing theoretical approaches while recognizing the diversity of policy paths to social policy restructuring in advanced industrial societies.

Daniel Béland is Associate Professor of Sociology at the University of Calgary, Canada.

Toshimitsu Shinkawa is Professor of Political Science at Kyoto University, Japan. 


\section{Notes}

The first draft of this article was presented on June 1, 2006 at the Policy History Conference in Charlottesville, Virginia. The authors would like to thank Martha Derthick, Junko Kato, Angela Kempf, John Myles, Monica Townsend, and two anonymous reviewers for their comments on previous drafts of this article.

1. The 1998 devolution of powers to Northern Ireland, Scotland, and Wales had virtually no impact on British pension reform. More importantly, devolution occurred 12 years after the enactment of the 1986 reform of SERPS, by far the most significant British pension legislation enacted since the 1970s.

2. This does not mean that policy drift is not at work in Britain and Japan. Yet, the fact that British and Japanese policy makers have relied extensively on legislative revision to reshape the public pension system means that policy drift is less crucial in these two countries than in the United States and Canada. Consequently, our analysis of the British and the Japanese cases focuses on legislative revision, not policy drift.

3. Regarding the public-private dichotomy, private benefits are indirectly related to public policies, especially tax benefits and regulations (Howard, 1997). As tax decisions affect private policies, the public-private dichotomy is more relative than absolute.

4. Under the intermediate assumptions, the OASDI cost rate is projected to decline slightly during 2006 through 2008 and then increase up to the current level within the next two years. It then begins to increase rapidly and first exceeds the income rate in 2017, producing cash-flow deficits thereafter. Despite these cash-flow deficits, beginning in 2017, redemption of trust fund assets will allow continuation of full benefit payments on a timely basis until 2040, when the trust funds will become exhausted (OASDI Trustees, 2006).

5. In 2003, the Pension Benefit Guaranty Corporation (PBGC) “insured about 29,500 single-employer defined-benefit plans, down from an all-time high of 112,000 plans in 1985. This decline primarily reflects a large number of terminations among small plans" (PBGC, 2003, p. 11).

6. "According to the Pension Plans in Canada Survey, at the end of 2001 about five-and-a-half million employees-representing $40 \%$ of all employees, including those in the public sector-had an RPP through their job (Chart A). This percentage was down from 45\% in 1991. Among men, coverage fell eight percentage points to $41 \%$; for women the drop was much less-from $41 \%$ to $39 \%$ " (Morissette \& Zhang, 2004, p. 11). These pension coverage numbers include both defined-benefit plans and definedcontribution plans.

7. In 1990, for example, 46.5 percent of British elderly households lived with an equivalent income below 50 percent average after social security benefits and direct taxation. This is higher than Canada (8.9 percent) and even the United States (40.5 percent) (Bradshaw \& Chen, 1998).

8. Meanwhile, the field of occupational pensions is witnessing major changes stemming partly from managerial decisions. Between 1979 and 2004, for example, membership in defined-benefit schemes declined from 6 to 3.5 million workers while membership in defined contribution schemes increase from 100,000 to about one million workers (Taylor-Gooby \& Mitton, 2006).

9. Historical description in this section was based mainly on Yokoyama and Tada (1991) and Yoshihara and Wada (1999).

10. There are a small number of corporate pension schemes unqualified for preferential tax treatment.

11. In Japan, the elderly only represented 7 percent of the population in 1971.

12. The case of the study of ideas is more complex but, to a certain extent, the "national values" perspective that Theda Skocpol and other historical institutionalist scholars have criticized is the clear ancestor of more recent approaches focusing on ideas and discourse.

13. Between 1980 and 1990, union membership in Britain declined from 52.9 to 40 percent. By 1999, fewer than 30 percent of British wage workers belonged to a labor union (Card et al., 2003). In Japan, the unionization rate declined from about 35 percent in 1975 to only 20 percent in 2002 (Japan Fact Sheet, 2005).

14. Following the historical institutionalist perspective, one can also note that the C/QPP is even more modest in scope than U.S. Social Security, which leaves plenty of room for private savings and private pensions. Considering the modest scope of the C/QPP (i.e., replacement rate of 25 percent), the incentive to privatize public pensions is lower in Canada than in the United States. 


\section{References}

Abelson, Donald E. 2002. Do Think Tanks Matter? Assessing the Impact of Public Policy Institutes. KingstonMontreal, Canada: McGill-Queen's University Press.

Banting, Keith G. 1987. "Institutional Conservatism: Federalism and Pension Reform.” In Canadian Social Welfare Policy: Federal and Provincial Dimensions, ed. Jacqueline S. Ismael. Kingston, Canada: McGillQueen's University Press, 48-74.

Battle, Ken (under the pseudonym of Grattan Gray). 1990. “Social Policy by Stealth.” Policy Options, 11 (2): 17-29.

Battle, Ken. 1997. "Pension Reform in Canada." Canadian Journal of Aging 16 (3): 519-52.

Béland, Daniel. 2007. Social Security: History and Politics from the New Deal to the Privatization Debate. Lawrence, KS: University Press of Kansas.

Béland, Daniel, and Jacob S. Hacker. 2004. "Ideas, Private Institutions, and American Welfare State 'Exceptionalism': The Case of Health and Old-Age Insurance, 1915-1965." International Journal of Social Welfare 13 (1): 42-54.

Béland, Daniel, and John Myles. 2005. "Stasis Amidst Change: Canadian Pension Reform in an Age of Retrenchment." In Ageing and Pension Reform Around the World, ed. Giuliano Bonoli and Toshimitsu Shinkawa. Cheltenham, UK: Edward Elgar Publishing, 252-72.

Berkowitz, Edward D. 2003. Robert Ball and the Politics of Social Security. Madison, WI: University of Wisconsin Press.

Blake, David. 2000. "Two Decades of Pension Reform in the UK: What Are the Implications for Occupational Pension Schemes?" Employee Relations 22: 223-45.

Bonoli, Giuliano. 2000. The Politics of Pension Reform. Cambridge, UK: Cambridge University Press.

Bradshaw, Jonathan, and Jun-Rong Chen. 1998. Poverty in the UK: A Comparison with Nineteen Other Countries [Online]. Heslington, UK: Social Policy Research Unit, University of York. http:// www.lisproject.org/publications/liswps/147.pdf. Accessed April 3, 2007.

Butler, Stuart, and Peter Germanis. 1983. "Achieving Social Security Reform: A Leninist Strategy." Cato Journal 3: 547-56.

Campbell, Andrea Louise. 2003. How Policies Make Citizens: Senior Citizen Activism and the American Welfare State. Princeton, NJ: Princeton University Press.

Campbell, John L. 2004. Institutional Change and Globalization. Princeton, NJ: Princeton University Press.

Card, David, Thomas Lemieux, and W. Craig Riddell. 2003. “Unionization and Wage Inequality.” Working Paper 9473, Washington, DC: National Bureau of Economic Research. http://ideas.repec.org/p/ nbr/nberwo/9473.html. Accessed March 3, 2007.

Cox, Robert H. 2001. "The Social Construction of an Imperative: Why Welfare Reform Happened in Denmark and the Netherlands but Not in Germany." World Politics 53: 463-98.

Derthick, Martha. 2001. "The Evolving Old Politics of Social Security." In Seeking the Center: Politics and Policymaking at the New Century, ed. Martin A. Levin, Marc K. Landy, and Martin Shapiro. Washington, DC: Georgetown University Press, 193-214.

Dionne, E. J. 2005. “End of the Bush Era." Washington Post (September 13): A27.

England, Robert Stowe. 2001. The Fiscal Challenge of an Aging Industrial World: A White Paper on Demographics and Medical Technology. Washington, DC: Center for Strategic and International Studies.

Esping-Andersen, Gøsta. 1990. The Three Worlds of Welfare Capitalism. Princeton, NJ: Princeton University Press.

, ed. 1996. Welfare States in Transition. Thousand Oaks, CA: Sage.

Esping-Andersen, G., and W. Korpi. 1984. "Social Policy as Class Politics in Postwar Capitalism: Scandinavia, Austria, and Germany." In Order and Conflict in Contemporary Capitalism, ed. J. Goldthorpe. Oxford: Oxford University Press, 179-208.

Fawcett, Helen. 2002. "Pension Reform in the UK." Paper presented at the Annual Meeting of the European Consortium for Political Research, March, Turin, Italy. 
Galenson, Walter. 1996. The American Labor Movement, 1955-1995. Westport, CT: Greenwood Press.

Glennerster, Howard. 2000. British Social Policy Since 1945, 2nd ed. London: Blackwell Publishing.

Hacker, Jacob S. 2002. The Divided Welfare State: The Battle over Public and Private Social Benefits in the United States. New York: Cambridge University Press.

—. 2004. "Privatizing Risk without Privatizing the Welfare State: The Hidden Politics of Social Policy Retrenchment in the United States." American Political Science Review 98 (2): 243-60.

Hall, Peter A. 1993. "Policy Paradigms, Social Learning and the State: The Case of Economic Policymaking in Britain." Comparative Politics 25 (3): 275-96.

HM Department of Health and Social Security. 1985. The Reform of Social Security: Programme for Action. London: HMSO.

Hinrichs, Karl, and Olli Kangas. 2003. "When is a Change Big Enough to be a System Shift? Small System Shifting Changes in German and Finnish pension policies." Social Policy and Administration 37 (6): 573-91.

Howard, Christopher. 1997. The Hidden Welfare State: Tax Expenditures and Social Policy in the United States. Princeton, NJ: Princeton University Press.

Huber, Evelyne, and John Stephens. 2001. Development and Crisis of the Welfare State: Parties and Policies in Global Markets. Chicago: University of Chicago Press.

Jacobs, Alan M., and Steven M. Teles. 2006. "The Perils of Market-Making: The Case of British Pension Reform." In The Politics and Economics of Creating Competitive Markets, ed. Martin Shapiro, Martin Levin, and Marc Landy. Washington, DC: Brookings Institution Press, 157-83.

Japan Fact Sheet. 2005. Employment: Meeting the Challenges of the Future [Online]. http://web-japan.org/ factsheet/employ/union.html. Accessed May 31, 2007.

Klein, Jennifer. 2003. For All These Rights: Business, Labor, and the Shaping of America's Public-Private Welfare State. Princeton, NJ: Princeton University Press.

Korpi, Walter. 1978. The Working Class in Welfare Capitalism. London: Routledge and Kegan Paul.

Korpi, Walter, and Joakim Palme. 2003. "New Politics and Class Politics in the Context of Austerity and Globalization: Welfare State Regress in 18 Countries." American Political Science Review 97 (3): 425-46.

Light, Paul C. 1995. Still Artful Work: The Continuing Politics of Social Security Reform. New York: McGraw-Hill.

Luchak, Andrew A., Tony Fang, and Morley Gunderson. 2004. "How Has Public Policy Shaped DefinedBenefit Pension Coverage in Canada?" Journal of Labor Research 25 (3): 469-84.

Martin, Paul. 1997. Tabling Draft Legislation to Amend the Canada Pension Plan. Ottawa, Canada: Minister of Finance to the House of Common.

Morissette, René, and Xuelin Zhang. 2004. "Retirement Plan Awareness." Perspectives (January): 11-18.

Myles, John. 1989. Old Age in the Welfare State, 2nd ed. Lawrence, KS: University Press of Kansas.

Myles, John, and Jill Quadagno. 2002. "Political Theories of the Welfare State." Social Service Review 76 (1): 34-57.

Nash, George H. 1996. The Conservative Intellectual Movement in America since 1945. Wilmington, DE: Intercollegiate Studies Institute.

Nenkin Joho Henshubu (Pension Information Editorial Office). 2003. Kigyo Nenkin no Shinjitsu [The Truth of Corporate Pension]. Tokyo: Nippon Keizai Shinbunsha.

OASDI Trustees. 2006. 2006 OASDI Trustees Report. Washington, DC: Office of the Chief Actuary.

PBGC. 2003. Pension Insurance Data Book 2003. Washington, DC: PBGC.

Pierson, Paul. 1994. Dismantling the Welfare State? Reagan, Thatcher, and the Politics of Retrenchment. New York: Cambridge University Press.

1 1996. "The New Politics of the Welfare State." World Politics 48 (1): 143-79.

- 2000. "Increasing Returns, Path Dependence, and the Study of Politics." American Political Science Review 94: 251-67.

. 2004. Politics in Time: History, Institutions, and Social Analysis. Princeton, NJ: Princeton University Press. 
Pierson, Paul, and R. Kent Weaver. 1992. "Imposing Losses in Pension Policy." In Do Institutions Matter? Government Capabilities in the U.S. and Abroad, ed. R. Kent Weaver, and Bert Rockman. Washington, DC: Brookings Institution.

Price, Debora. 2007. "Closing the Gap in Retirement Income: What Difference Will Recent UK Pension Reform Make?" Journal of Social Policy 36 (4): 561-83.

Prince, Michael J. 2000. "Apocalyptic, Opportunistic, and Realistic Discourse." In The Overselling of Population Aging, ed. Ellen M. Gee and, Gloria M. Gutman. Don Mills, Ontario: Oxford University Press, 100-14.

Quadagno, Jill. 1999. "Creating a Capital Investment Welfare State." American Sociological Review 64 (1): $1-10$.

Reform Party. 1998. Can Your Pension Be Saved? Ottawa, May.

Sass, Steven A. 1997. The Promise of Private Pension: The First Hundred Years. Cambridge, MA: Harvard University Press.

Schmidt, Vivien A. 2002. "Does Discourse Matter in the Politics of Welfare State Adjustment?" Comparative Political Studies 35 (2): 168-93.

Shinkawa, Toshimitsu. 2005. "The Politics of Pension Reform in Japan: Institutional Legacies, CreditClaiming and Blame Avoidance." In Ageing and Pension Reform around the World, ed. G. Bonoli, and T. Shinkawa. Cheltenham, UK: Edward Elgar Publishing, 157-81.

Skocpol, Theda. 1992. Protecting Soldiers and Mothers: The Political Origins of Social Policy in the United States. Cambridge, MA: Harvard University Press.

Statistics Canada. 2004. Study: Using RRSPs Before Retirement [Online]. Ottawa, Canada: Statistics Canada. http:/ / www.statcan.ca/Daily/English/041215/d041215d.htm. Accessed December 15, 2006.

Streek, Wolfgang, and Kathleen Thelen, eds. 2005. Beyond Continuity: Policy Change in Advanced Political Economies. Oxford: Oxford University Press.

Taylor-Gooby, Peter. 2005. “UK Pension Reform: A Test Case for a Liberal Welfare State?" In Ageing and Pension Reform around the World, ed. Giuliano Bonoli, and Toshimitsu Shinkawa. Cheltenham, UK: Edward Elgar Publishing, 116-136.

Taylor-Gooby, Peter, and Lavinia Mitton. 2006. "Much Noise, Little Progress: The UK Experience for Privatization." Unpublished Paper, University of Kent.

Teles, Steven M. 1998. "The Dialectics of Trust." Paper presented at the Annual Meeting of the Association for Public Policy Analysis and Management.

Thelen, Kathleen. 2004. How Institutions Evolve: The Political Economy of Skills in Germany, Britain, the United States, and Japan. Cambridge, UK: Cambridge University Press.

Townson, Monica. 2001. Pensions Under Attack. Toronto: Lorimer/Canadian Centre for Policy Alternatives.

Weaver, R. Kent. 1986. "The Politics of Blame Avoidance." Journal of Public Policy 6 (4): 371-98.

2005. "Public Pension Reform in the United States." In 2005 Ageing and Pension Reform Around the World, ed. Giuliano Bonoli and Toshimitsu Shinkawa. Cheltenham, UK: Edward Elgar, 230-51.

Wilensky, Harold L. 1975. The Welfare State and Equality: Structural and Ideological Roots of Public Expenditures. Berkeley: University of California Press.

Yokoyama, Kazuhiko, and Hidenori Tada. 1991. Nippon Shakai Hoso no Rekishi. Tokyo: Gakubunsha.

Yoshihara, Kenji, and Masaru Wada. 1999. Nippon Iryo Hoken Seidoshi. Tokyo: Toyo Keizai Shinposha. 